\title{
Soil Quality and Water Redistribution Influences on Plant Production over Low Hillslopes on Reclaimed Mined Land
}

\author{
Stephen D. Merrill $\left(\mathbb{D},{ }^{1}\right.$ Mark A. Liebig ${ }^{(D},{ }^{1}$ John D. Hendrickson, ${ }^{1}$ and Abbey F. Wick ${ }^{2}$ \\ ${ }^{1}$ Northern Great Plains Research Laboratory, Agricultural Research Service, U.S. Department of Agriculture, P.O. Box 459, \\ 1701 10th Ave. SW, Mandan, ND 58554, USA \\ ${ }^{2}$ Department of Soil Science, Walster Hall, North Dakota State University, Department 7680, P.O. Box 6050, \\ Fargo, ND 58108-6050, USA \\ Correspondence should be addressed to Stephen D. Merrill; steve.merrill@ars.usda.gov
}

Received 13 December 2017; Accepted 17 March 2018; Published 26 April 2018

Academic Editor: Glaciela Kaschuk

Copyright (C) 2018 Stephen D. Merrill et al. This is an open access article distributed under the Creative Commons Attribution License, which permits unrestricted use, distribution, and reproduction in any medium, provided the original work is properly cited.

Coal surface mining in northern Great Plains USA led to reclamation experiments with soil respreading. Respread soil depth (RSD) and runoff of water redistribution (WR) effects interacted in original North Dakota studies, complicating interpretations. We determined WR and soil depth/soil quality (SQ) effects on hillslope production patterns for sites with soil wedges ( $2 \%-5 \%$ slope, 50-m length) over sodic mine spoils. At Zap, cool-season forages crested wheatgrass (CWG: Agropyron cristatum) and Russian wildrye (Psathyrostachys juncea) generally decreased as RSD increased upslope. At Stanton, alfalfa (Medicago sativa), native grasses (Bouteloua spp.), and CWG responded to RSD, increasing 70\% to midslope and decreasing further. A SQ index (SQI) based on six indicator properties was highly correlated $(r>0.7)$ with RSD. Yield regressions with RSD or SQI were generally significant for Stanton forages and for spring wheat (Triticum aestivum) at both sites. Yield regressions with WR index (catchment areabased) indicated dominance of WR effects at Zap. Cool-season forages at Zap evidently responded to springtime runoff, while Stanton forages and spring wheat at both sites used water later in the season and responded to soil depth/SQ effects. Results suggest models for interaction of SQ and landform WR affecting productivity should include plant community composition and water-use information.

\section{Introduction}

A need for land reclamation was created by the advent of coal surface mining in the northern Great Plains of the USA. In portions of this region Paleocene strata can give rise to mine spoil high in exchangeable sodium and clay content making revegetation difficult $[1,2]$. Reclamation experiments using soil salvage and respreading were initiated by Power and colleagues in the state of North Dakota $[1,2]$. Reclaimed landforms in these experiments were hillslopes with $2 \%$ to $5 \%$ slopes and about 50-m in length, and interactions of landform water redistribution (WR) and soil depth effects complicated interpretation of productivity results. The experiments occurred before full development of current methods for analyzing soil quality (SQ) and landform WR. Thus a principal goal of this study is to quantify relative effects of soil depth SQ and WR on productivity and the role of plant community in modifying such effects.

In one experiment near Stanton ND [2], a wedge of Haplustoll subsoil material (B and C horizons, 0 to $2.4 \mathrm{~m}$ thick) was placed over mine spoil and covered with 0 -, 20-, or 60- $\mathrm{cm}$ of topsoil material (A-horizon; Figure 1(a)). Production of three perennial forage species and spring wheat increased with soil depth to midslope and then declined somewhat further upslope.

In another experiment near Zap ND [3], a double wedge, consisting of three different types of Haplustoll subsoil materials 0 to $1.2 \mathrm{~m}$ thick, was covered with $20 \mathrm{~cm}$ of topsoil (Figure 1(b)). Response of two perennial forage species to soil depth was weak or nonexistent and yields generally declined as soil depth increased upslope. However, yield patterns of spring wheat at Zap were similar to those at Stanton. It 


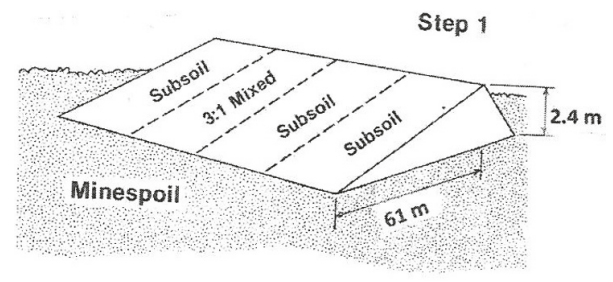

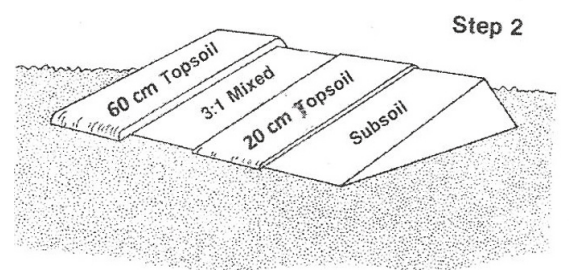

(a)

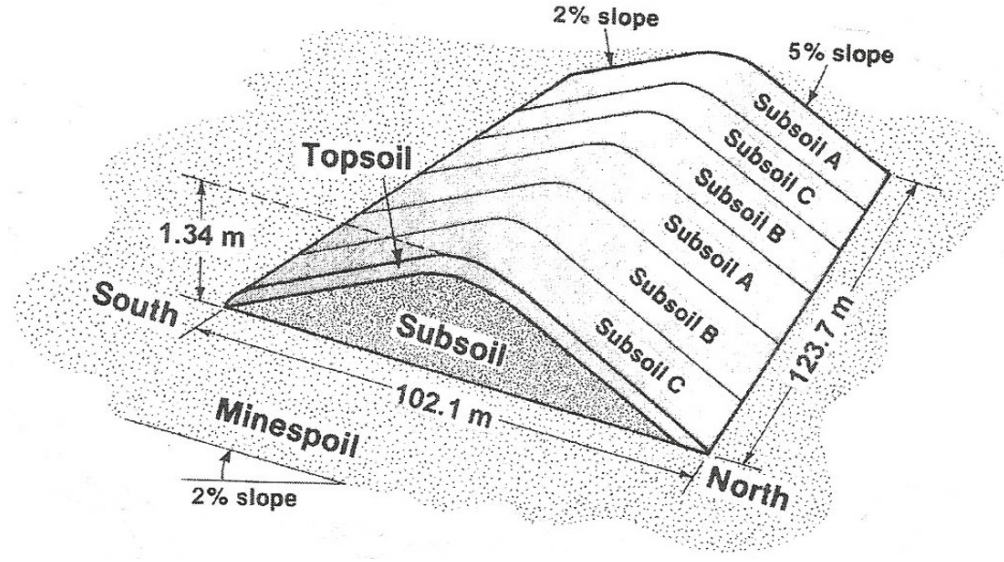

(b)

Figure 1: (a) One replication out of three of reconstructed soils at Stanton site. Overall length of construct was $243 \mathrm{~m}$ and average slope was 4\%. The 3:1 mixed subsoil : topsoil treatment is not discussed in this paper. (b) Reconstructed soil at Zap site. Modified from Doll et al. [1].

was hypothesized [3] that water redistribution affected the hillslope patterns of forage species' yields at Zap.

The influence of soil depth where water redistribution influence should have been minimal was shown by results of Barth and Martin [4] from experiments in which they created flat-surfaced wedges of soil that were placed down into sodic mine spoils. They observed an increase of forage grass production to a soil depth of $0.7 \mathrm{~m}$ out of $1.5 \mathrm{~m}$, with plateauing of growth at greater soil depths.

Runoff of water to lower areas of hillslopes results in higher yields downslope.

Working on pastures dominated by cool-season grasses in Iowa USA, Harmoney et al. [5] found that yields over hillslope positions ran in the order toeslope $>$ summit $>$ backslope. Under xeric climate in the Pacific Northwest USA, Fiez et al. [6] found that wheat yield was correlated with water use, which was generally higher at footslope or backslope positions.

Results of North Dakota-based reclamation experiments, particularly in terms of production responses to respread soil depth over mine spoils [1], have been applied to state reclamation requirements [7]. However, original interpretations of the reclamation experiments $[2,3]$ have left important questions unanswered that should be amenable to modern forms of soil analyses, particularly application of the soil quality (SQ) concept. Soil depth over mine spoil is a measure of soil quality (SQ). To better assure scientifically valid application of reclamation experiments featured here, the relative roles of soil depth/SQ and water redistribution in plant production responses need to be elucidated through application of current SQ assessment and landscape analysis practices.

The basic definition of SQ is the capacity of a soil to function [8]. A system for assessing SQ has been described by Andrews and coworkers $[9,10]$ in which a set of SQ indicator properties are chosen, the value of each indicator towards an endpoint (such as crop production) is scored, and scoring values are aggregated into a SQ index (SQI).
Indices that quantify characteristics of landforms have been reviewed [11]. Water redistribution on hillslopes has been linked to these terrain indices [12]. To best serve the specific needs of the current study, we have selected a basic terrain index based on catchment area [11, 12] for use as a hillslope water redistribution index (WRI).

The objective of this study was to determine the relative effects of SQ measures (soil depth and SQI) and apparent water redistribution (represented by WRI) upon hillslope plant production patterns on reclaimed mine soils. Other factors whose effects on plant production patterns have been studied here were plant species and structure of reclaimed soils.

\section{Research Methods}

2.1. Experimental Mined Land Reclamation Sites. Experimental reclamation sites were located in Mercer county, North Dakota, USA, near the towns of Zap and Stanton at $47^{\circ} 14^{\prime} 33^{\prime \prime} \mathrm{N}-101^{\circ} 51^{\prime} 1^{\prime \prime} \mathrm{W}$ and $47^{\circ} 15^{\prime} 30^{\prime \prime} \mathrm{N}-101^{\circ} 20^{\prime} 55^{\prime \prime} \mathrm{W}$, respectively. Mean annual precipitation was $421 \mathrm{~mm}$, with $270 \mathrm{~mm}$ occurring during the 6-mo April-September growing season, and the mean 6-mo growing season temperature was $15.6^{\circ} \mathrm{C}$.

Coal surface mining at the sites produced spoil from Mesozoic strata consisting of loosely consolidated siltstone or shale material that is saline and sodic. At the Zap site, mine spoil was leveled in 1974-1975 to a 2\% north-facing slope. After removal and stockpiling of nearby Haplustoll topsoil material (mostly A-horizon), three types of subsoil materials (mostly B- and C-horizon) were placed in a double wedgeshaped hillslope with 21-m wide main treatment (subsoil quality) areas with two replications (Figure 1(b); Table 1).

Topsoil (mostly A-horizon) was spread over subsoils to a depth of $20 \mathrm{~cm}$. At the Stanton site, spoil was leveled in 1974 to a $0.5 \%$ slope and a single wedge of subsoil material was formed. Main treatment strips 20 -m wide with three 
TABLE 1: Soil properties at experimental reclamation sites. AWC, available water content; EC, electrical conductivity; SAR, sodium adsorption ratio; SOC, soil organic carbon.

\begin{tabular}{|c|c|c|c|c|c|c|c|c|}
\hline & \multicolumn{5}{|c|}{ Zap reclamation site } & \multicolumn{3}{|c|}{ Stanton reclamation site } \\
\hline & Topsoil & Subsoil A & Subsoil B & Subsoil C & Minespoil & Topsoil & Subsoil & Minespoil \\
\hline Sand, $\mathrm{g} \mathrm{kg}^{-1}$ & 410 & 82 & 315 & 679 & 80 & 526 & 246 & 74 \\
\hline Silt, $\mathrm{g} \mathrm{kg}^{-1}$ & 349 & 443 & 420 & 187 & 482 & 341 & 425 & 563 \\
\hline Clay, $\mathrm{g} \mathrm{kg}^{-1}$ & 241 & 475 & 265 & 134 & 438 & 133 & 329 & 363 \\
\hline Texture, USDA system & Loam & Silty clay & Clay loam & Sandy loam & Silty clay & Sandy loam & Clay loam & Silty clay loam \\
\hline AWC, $\mathrm{kg} \mathrm{kg}^{-1}$ & 0.174 & 0.147 & 0.149 & 0.096 & 0.128 & 0.190 & 0.157 & 0.157 \\
\hline Bulk density, $\mathrm{g} \mathrm{cm}^{-3}$ & 1.211 & 1.251 & 1.331 & 1.448 & 1.353 & 1.279 & 1.279 & 1.340 \\
\hline${ }^{\$} \mathrm{EC}_{1: 1}, \mathrm{dS} \mathrm{m}^{-1}$ & 1.32 & 4.76 & 2.29 & 0.79 & 5.86 & 0.60 & 2.99 & 3.05 \\
\hline $\mathrm{SAR},\left(\mathrm{mol} \mathrm{m}^{-3}\right)^{1 / 2}$ & 4.86 & 7.67 & 6.77 & 5.46 & 17.30 & 3.47 & 9.96 & 16.40 \\
\hline Saturation $\%$ & 41.2 & 60.1 & 48.5 & 27.4 & 99.6 & 41.0 & 62.7 & 112.4 \\
\hline${ }^{\$} \mathrm{pH}_{\mathrm{se}}$ & 7.16 & 7.36 & 7.73 & 7.07 & 7.54 & 7.37 & 7.91 & 7.95 \\
\hline SOC, $\mathrm{g} \mathrm{kg}^{-1}$ & 14.3 & 9.7 & 7.1 & 7.2 & $8.5^{\#}$ & 15.6 & 8.1 & $9.5^{\#}$ \\
\hline Total $N, \mathrm{~g} \mathrm{~kg}^{-1}$ & 1.16 & 0.80 & 0.60 & 0.69 & 0.71 & 1.3 & 0.7 & 0.3 \\
\hline available $\mathrm{P}, \mathrm{mg} \mathrm{kg}^{-1}$ & 9.2 & 11.4 & 3.6 & 6.7 & 7.1 & 8.7 & 4.0 & 4.9 \\
\hline
\end{tabular}

$\$$ Note that EC was on 1:1 gravimetric basis and $\mathrm{pH}$ was from saturation extracts. ${ }^{\text {}}$ Values may be elevated to some greater or lesser degree by presence of leonardite (partially oxidized lignite).

replications were created by placement of $0-, 0.2-$, and $0.6-\mathrm{m}$ thicknesses of topsoil over subsoil (Figure 1(a); Table 1).

Each soil type block was divided lengthwise and four crop treatments were seeded in a randomized pattern within replications. Species seeded at Zap in 1976 were the perennial, cool-season grasses Russian wildrye (RWR; Psathyrostachys juncea) and crested wheatgrass (CWG; Agropyron cristatum) and spring wheat (Triticum aestivum). A fourth species, alfalfa (ALF; Medicago sativa), did not establish well and was not used for research purposes. Species seeded at the Stanton in 1975 were ALF, CWG, spring wheat, and a native, perennial, warm-season grass mix (NAT) consisting of blue grama (Bouteloua gracilis) and sideoats grama (Bouteloua curtipendula). Before seeding, 67 and $35 \mathrm{~kg} \mathrm{ha}^{-1} \mathrm{P}$ as triple superphosphate were broadcast on all subplots at Zap and Stanton, respectively. All subplots except those to be seeded to ALF received $55 \mathrm{~kg} \mathrm{~N} \mathrm{ha}^{-1}$ as ammonium nitrate every year through 1978. Spring wheat received $12 \mathrm{~kg} \mathrm{Pha}^{-1}$ deposited with seed.

2.2. Plant Productivity. Crops were harvested from 1976 to 1979 at the Stanton site and 1976 to 1981 at the Zap site, but, for purposes of this paper, data from 1978 and 1979 are used because they were years without drought in which both sites were represented. Vegetation was harvested from areas $4.3 \mathrm{~m}$ long by $1.8 \mathrm{~m}$ wide at 10 or 11 positions along each aspect of hillslopes, and dry weights of forage species' aboveground herbiage and spring wheat seed yields were measured. Forage grasses were harvested in late June or early July, and ALF was harvested twice, in late June or early July and again in August or early September. Spring wheat seed was harvested from the later part of July to the first part of August.

Relative yields were calculated for each seeding treatment based on the yearly average for the treatment at a site. Yield patterns of individual forage species' treatments were compared using running averages of three contiguous hillslope positions (1, 2, 3; 2, 3, 4; etc.). Applying one-way ANOVA to such averages normalized to annual treatment means, only 6 out of 132 site-position-soil treatment-year combinations indicated significant yield differences. Therefore, relative yields for a given year and site were aggregated among forage species treatments for further analyses.

2.3. Soil Measurements. Soil samples were collected by hydraulic probe in depth increments of $0-15,15-30,30-60$, $60-90$, and $90-120 \mathrm{~cm}$. Samples for electrical conductivity (EC) and $\mathrm{pH}$ were collected at four positions from toe to summit along each hillslope aspect and those for SOC and available $\mathrm{P}$ at either one or two positions.

Soil chemical measurements were conducted by methods detailed in Black et al. [13] adapted to requirements of mined land reclamation research [14]. Soluble cations were determined on saturation extracts by atomic adsorption, and sodium adsorption ratio (SAR) was calculated. Electrical conductivity was determined on saturation extracts [15] and $\mathrm{pH}$ was determined on saturated paste [16]. Saturation extract EC (but not $\mathrm{pH}$ ) values were converted into 1:1 (mass) basis using the ExtractChem model [17] for purposes of comparison with subsequent soil sampling and analyses. SOC was determined by wet oxidation [18] and available $\mathrm{P}$ by bicarbonate technique [19].

Details about samples used for textural analysis are given in Wick [20]. Soil texture was determined by hydrometer technique [21]. Available water content (AWC, defined as water held by soil between matric potentials of $-0.33 \mathrm{kPa}$ and $-1.5 \mathrm{kPa}$ ) was calculated from textural values and organic carbon according to Gupta and Larson [22] using soil bulk density values from [20]. SOC values were multiplied by 2.0 to obtain organic carbon. Additional details about the experiments may be found in $[2,3]$.

2.4. Soil Quality. Soil quality assessment was carried out by calculation of a SQ index (SQI) using the SMAF tool 
TABLE 2: Precipitation at experimental reclamation sites near Zap and Stanton, North Dakota, USA. Annual median precipitation near the sites at Beulah ND for 29-year period was $39.2 \mathrm{~cm}$.

\begin{tabular}{|c|c|c|c|c|c|}
\hline \multirow[b]{2}{*}{ Month } & \multicolumn{3}{|c|}{ Zap } & \multicolumn{2}{|c|}{ Stanton } \\
\hline & 1978 & 1979 & $\begin{array}{c}29-y r \text { median } \\
1975-2003\end{array}$ & 1978 & 1979 \\
\hline & & & $\mathrm{cm}$ & & \\
\hline April & 4.4 & 4.5 & 3.4 & 4.2 & 3.2 \\
\hline May & 5.8 & 2.0 & 5.7 & 5.2 & 2.7 \\
\hline June & 6.4 & 6.1 & 7.5 & 8.8 & 7.2 \\
\hline July & 7.8 & 11.4 & 6.1 & 6.2 & 7.9 \\
\hline August & 1.5 & 2.3 & 3.0 & 0.9 & 12.3 \\
\hline September & 4.1 & 3.2 & 3.2 & 8.8 & 2.5 \\
\hline April through September & 29.9 & 29.5 & 28.9 & 34.1 & 35.8 \\
\hline
\end{tabular}

developed by Andrews et al. [10]. In this method of SQ assessment, the first step is selection of a minimum number of properties related to an end point of interest, such as crop production. We have used six available properties, SAR, EC, pH, SOC, AWC, and available P. For each SQ indicator property, a scoring value from 0 to 100 was calculated according to the property's capacity to support crop production. Scoring functions [10] were all monotonic over ranges of interest here and were either "less is better" (SAR, EC, and $\mathrm{pH}$ ) or "more is better" (SOC, AWC, and available $\mathrm{P})$. Scoring values were averaged with equal weights [9] to yield a SQI value. Values were calculated for individual soil depths and then integrated over $0-90 \mathrm{~cm}$. This depth range produced the highest average $R^{2}$ values for yield versus soil property regressions (data not shown).

In order to calculate a SQI value for each of the 8 or 10 positions along hillslopes at which plant yields were measured, soil property values were estimated from measured values. For the chemical properties EC, SAR, and $\mathrm{pH}$, measured at four locations, this was done by interpolation on treatment averages for each sampling depth increment. For the properties SOC, available $\mathrm{P}$, and AWC, treatment averages for reconstructed soil horizons (topsoil, subsoil, or mine spoil) and soil depths were used to derive suitable values.

2.5. Water Redistribution. Water content measurements were examined for indications of downslope water redistribution. Neutron moisture meters had been used in steel access tubes, which had been installed two per subplot at a lower midslope and a near-summit position. Although measurements were made over multiple years, only 1979 data had been analyzed by individual depth increments in predecessor studies, making them suitable for indicating downslope water redistribution. Out of measurements made five times during the year, only those in late April-early May showed substantial evidence of water redistribution in the $0-30 \mathrm{~cm}$ soil depth. (The $0-30 \mathrm{~cm}$ depth was the only increment where water content differences between the upper and lower hillslope positions had not been affected by systematic variation in respread soil depth.) ANOVA was done across soil treatments within seeding treatments. Averaged across soil treatments,
0-30 cm soil water at Zap under CWG was $14 \%$ greater at the lower hillslope position (water content $=0.21 \mathrm{~m}^{3} \mathrm{~m}^{-3}, p$ of greater $F=0.023$ ). Lower versus upper position differences averaged 9\% for ALF and RWR treatments (ns). At Stanton, average soil water under CWG was $4 \%$ greater at the lower hillslope position (water content $=0.23 \mathrm{~m}^{3} \mathrm{~m}^{-3}, p$ of greater $F=0.054)$. At Stanton, almost all indication of greater water content at the lower position was for the $0 \mathrm{~cm}$ topsoil treatment, with an average increase of $7 \%$.

Moore et al. [11] have reviewed terrain attribute indicators based on catchment area, aspect, slope, and curvature. Western et al. [12] have examined relationships between landscape soil water distributions and various terrain indices. Given the simple landform of the low hillslopes involved here and the differences in aspect between the two sites, catchment area has been used here as a water redistribution index (WRI):

$$
\mathrm{WRI}=\ln (d),
$$

where $d$ is distance (in $\mathrm{m}$ ) downslope from the summit.

2.6. Statistical Analyses. One-way ANOVA of individual seeding treatments' yields used SPC for Excel (BPI Consulting; Cypress, Texas, USA). Soil water data was analyzed within site, depth, and seeding treatment by ANOVA with hillslope location as split plot within soil treatment using SAS 79 (SAS Enterprises Inc., Cary, North Carolina, USA). Correlations among soil properties and indices and regressions of plant production versus WRI and SQ metrics used SPC for Excel. Regressions of plant production versus hillslope position used Sigma Plot (Systat Software, Inc., San Jose, California, USA).

\section{Results and Discussion}

3.1. Patterns of Plant Production. Growing season precipitation at Zap and Stanton during the years of the study was average or above average (Table 2). However, precipitation in May 1979 was half or less of average at both sites.

Except for ALF, yields of perennial forages and spring wheat at both sites were considerably higher in 1978 than in 
TABLE 3: Biomass yields of perennial forage species or seed yield of spring wheat.

\begin{tabular}{lcccccc}
\hline Site & Year & Crested wheatgrass & Native grass mix & $\begin{array}{c}\text { Russian wildrye } \\
\mathrm{kgha}^{-1}\end{array}$ & Alfalfa & Spring wheat \\
\hline \multirow{2}{*}{ Zap } & 1978 & 3103 & & 2134 & 811 \\
& 1979 & 1418 & & 1149 & & 1639 \\
\hline \multirow{2}{*}{ Stanton } & 1978 & 4023 & 1462 & & 2194 & 2327 \\
& 1979 & 1599 & 861 & & & \\
\hline
\end{tabular}

1979, reflecting a better distribution of spring precipitation during 1978 (Table 3). At Zap, yields of perennials were not significantly different among subsoil treatments in 1978 but about $25 \%$ greater on subsoil C than on A or B in 1979 (data not shown). Spring wheat seed yield in 1978 was about $50 \%$ greater on subsoil A than on subsoil C, where it was least. For perennials and spring wheat at Stanton, the two topsoiled treatments had $20 \%$ to $30 \%$ higher yields than the treatment with subsoil alone.

Three out of six 1978-79 regressions of aggregated CWG and RWR yields versus hillslope position on the Zap 5\% north-facing slope had about $20 \%$ to $45 \%$ increases with greater soil depths and elevations to $10 \mathrm{~m}$ or more from the toe of the soil wedge (Figure 2). However, decreases in yield further upslope with increasing soil depth and elevation were greater over the majority of the length at Zap northfacing slope. Five out of six regressions had $0.07>p>$ 0.001 . These growth patterns were indicative of apparent water redistribution effects. The soil treatment with subsoil C (sandy loam, nonsaline, Table 1) showed the largest increases and decreases of yield. Only two out of six regressions were significant on the $1.5 \%$ south-facing slope at Zap.

On the 4\% south-facing slope at Stanton, 1978-79 relative yields of the three (ALF, CWG, and NAT) forage species aggregated showed up to about $60 \%$ increases of production with increasing soil depth and elevation to midslope and then smaller decreases of yield further upslope (Figure 3). Five of six regressions were highly significant and $p=0.06$ for one. These patterns at Stanton were indicative of a greater response to soil depth and a lesser response to apparent water redistribution compared with patterns at the Zap site. Figure 3 indicates the consistently higher yields of the $20 \mathrm{~cm}$ and $60 \mathrm{~cm}$ topsoil treatments compared with the no topsoil treatment.

Hillslope patterns of perennial forages' yields have been aggregated across soil treatments and compared with those of spring wheat seed yields for the year 1978 in Figure 4. At Zap $5 \%$ north-facing slope, the spring wheat production pattern was quite different from that of forage species, approximately doubling from toe to midslope, then decreasing somewhat with greater soil depth towards the summit. Spring wheat production also differed greatly from the yield pattern of forages at the $1.5 \%$ Zap south-facing slope, increasing by well over $100 \%$ with soil depth from toeslope to near summit. The hillslope pattern of spring wheat production at Stanton was very similar to that of perennial forages.

Hillslope water redistribution generated by runoff is sensitive to slope $[11,12]$. This is illustrated by comparison of forage production patterns for soil treatments on Zap northfacing versus south-facing slopes ( $5 \%$ versus $1.5 \%$, resp.) in Figure 2, and by the same north/south comparison of Zap forages with spring wheat in Figure 4. In particular, the pattern of spring wheat production on the low southfacing slope at Zap appears to be free of any apparent water redistribution effect.

3.2. Analysis of Plant Production over Hillslopes. To understand results of regressions of plant productivity with measures of SQ and water redistribution, we examined correlations among various soil properties and indices (Table 4). Given the basic wedge-shaped design of the experiments, the two measures of SQ used here, RSD and SQI, were highly and positively correlated with distance from toe of each hillslope, and WRI was negatively correlated with distance (a). SQ measures RSD and SQI were strongly related, $R^{2}$ $=0.890$ and 0.689 for Zap and Stanton sites, respectively (b). And WRI was negatively correlated to SQ measures. Chemical soil properties SAR, EC, and $\mathrm{pH}$ were negatively correlated with SQI at both sites, reflecting "more is less" SQ scoring functions (c). Soil properties AWC, SOC, and P were positively correlated with SQI at Stanton, but only P was correlated with SQI at Zap.

At Zap, subsoil B and C treatments had positive regressions of forage species production with water redistribution index (WRI); the subsoil A regression was near significant (Table 5). Water redistribution is sensitive to slope, and this was shown by comparison of yield versus WRI regressions for Zap north-facing slope versus south-facing, with $R^{2}$ values of 0.228 and 0.045 , respectively (data not shown). All regressions between yield and SQ measures RSD and SQI at Zap had negative regression coefficients, evidently a consequence of negative correlations between WRI and SQ measures (see Table 4).

Multilinear regressions combining RSD or SQI with WRI also had negative coefficients for the SQ measure part of the equations. Positive regressions with WRI and negative coefficients for regressions with SQ measures reflected evident dominance of water redistribution effects on hillslope yield patterns.

In contrast to Zap, only multilinear regressions of yield versus RSD and WRI or yield versus SQI and WRI were significant at Stanton and then only for the two treatments with topsoil (Table 5). Plant yield versus hillslope position functions at Stanton were nonlinear to an extent that made linear regressions of yield versus WRI or SQ measures 

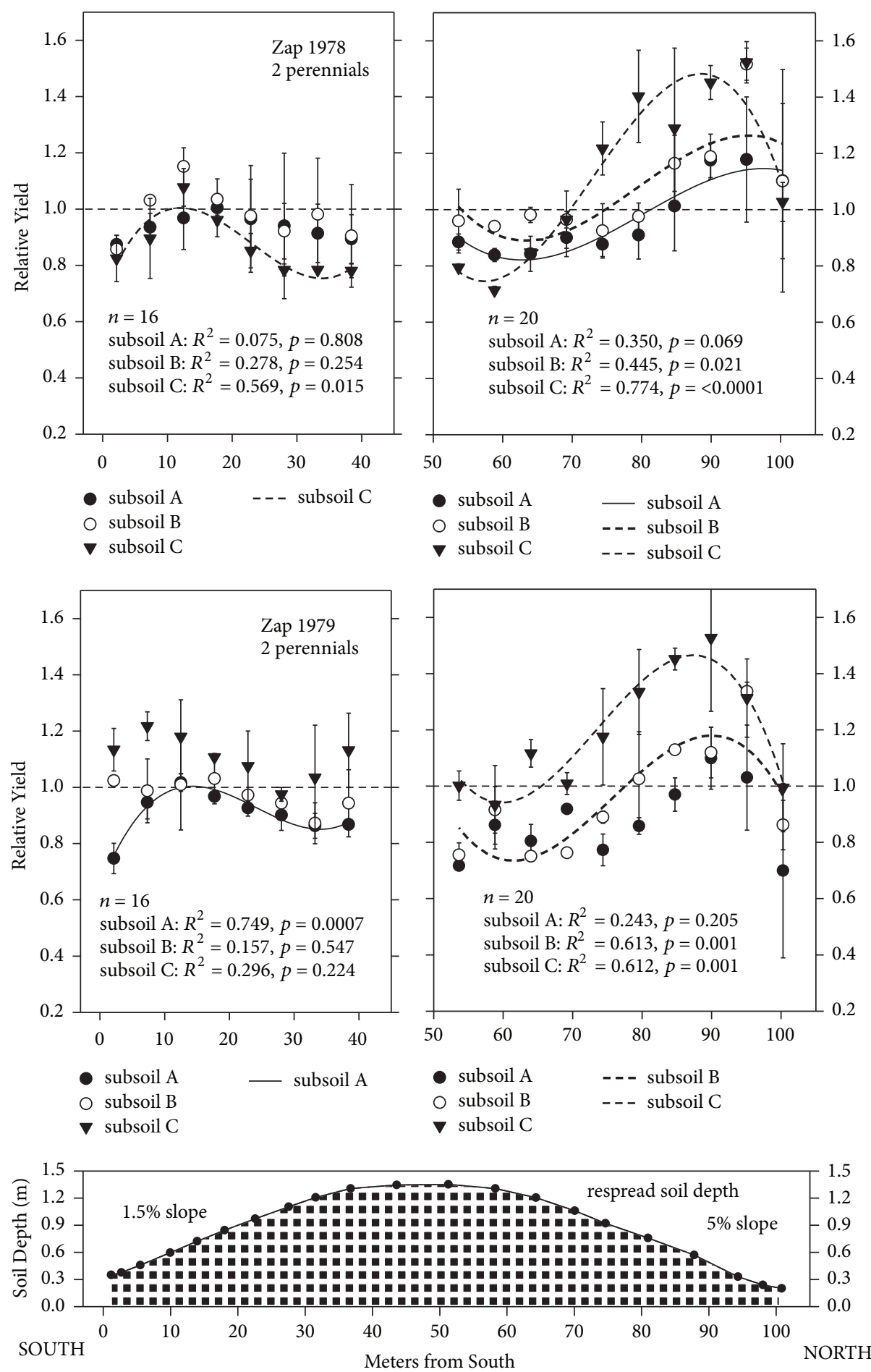

FIGURE 2: Relative yields of perennial forage crops versus hillslope positions for soil treatments at Zap site during 1978 and 1979 showing means, standard errors, and cubic regressions. Yields of crested wheatgrass (Agropyron cristatum) and Russian wildrye (Psathyrostachys juncea) have been aggregated.

nonsignificant (see Figure 3). All regression coefficients in significant equations shown for Stanton were positive.

Regressions of yield versus WRI and SQ measures comparing 1978 spring wheat seed and perennial forage biomass indicated that spring wheat at Zap displayed a pattern of results similar to those of both spring wheat and perennials at Stanton (regressions aggregated across soil treatments; Table 6). Spring wheat at both sites and perennials at Stanton had positive linear and multilinear regressions with SQ measures in 1978, while perennials at Zap had negative 

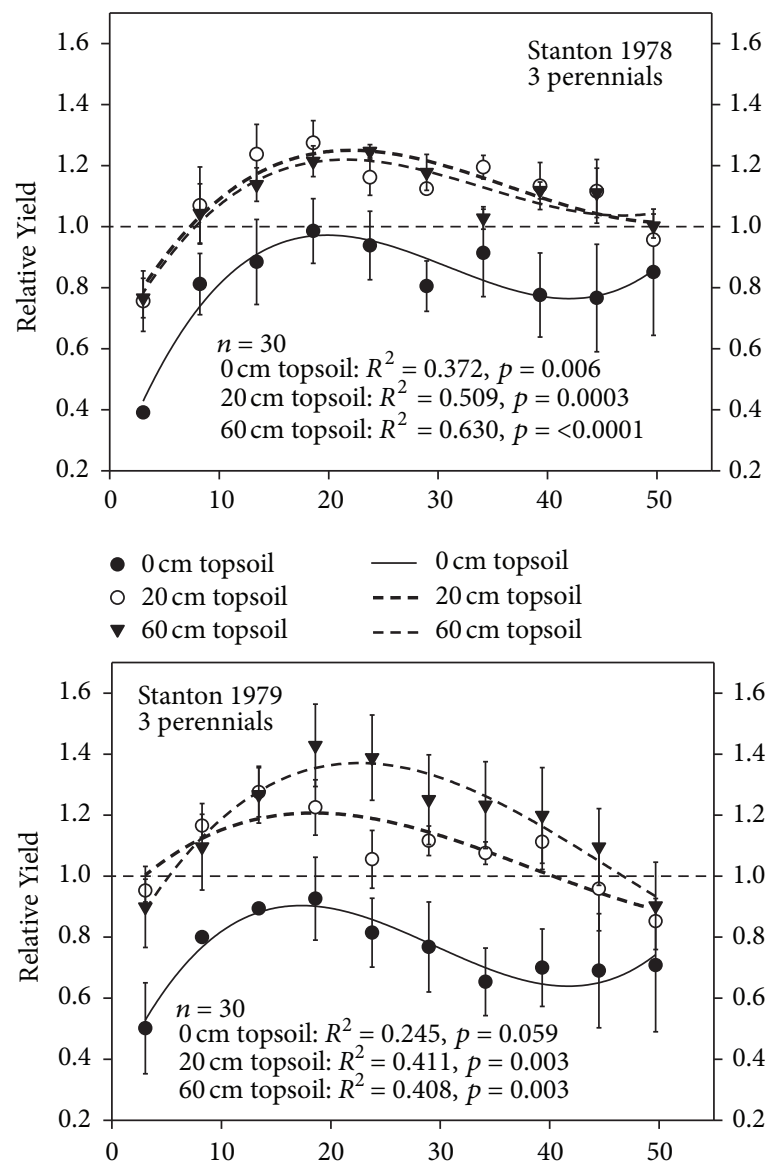

$$
\begin{array}{ll}
\text { - } 0 \mathrm{~cm} \text { topsoil } & -0 \mathrm{~cm} \text { topsoil } \\
\text { ○ } 20 \mathrm{~cm} \text { topsoil } & ---20 \mathrm{~cm} \text { topsoil } \\
\text { จ } 60 \mathrm{~cm} \text { topsoil } & ---60 \mathrm{~cm} \text { topsoil }
\end{array}
$$

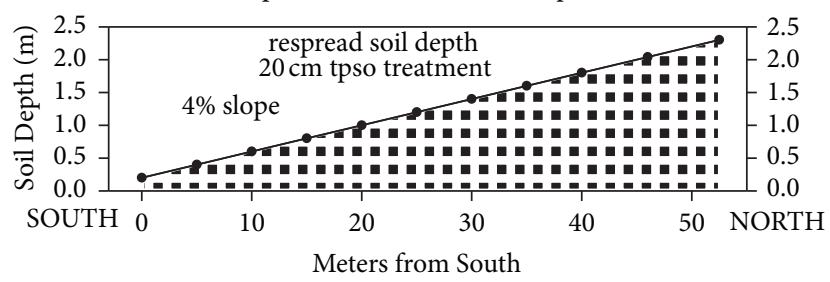

FIGURE 3: Relative yields of perennial forage crops versus hillslope positions for soil treatments at Stanton site during 1978 and 1979 showing means, standard errors, and cubic regressions. Yields of alfalfa (Medicago sativa), crested wheatgrass (Agropyron cristatum), and native mix (blue grama, Bouteloua gracilis, and sideoats grama, Bouteloua curtipendula) have been aggregated.

coefficients as was also shown for regressions based on individual soil treatments in Table 5.

Differences in hillslope production patterns and regression results between forage species and spring wheat at Zap appear to be related to when the species are most actively using soil water and growing during the spring and summer. Perennial grasses at Zap, CWG, and RWR are both coolseason species, actively growing in earlier spring. Under North Dakota USA conditions, CWG reaches boot stage by late May to about June 1 [23], whereas, in the same area, spring wheat reaches boot stage around the last week of June to about the beginning of July and accumulates seed mass up to the end of July [24]. In a semiarid area, water redistribution in springtime should affect cool-season forages. Later water use and growth by spring wheat would rely more upon stored soil water, making growth more responsive to soil depth/SQ effects.

Two out of three forage species at Stanton were either warm-season (NAT mix) or full season (twice-cut ALF). As noted above, there were very few differences among hillslope growth patterns of individual forage species, and this applied to cool-season CWG compared to the other forage species at Stanton. Thus, the principal reason for differences in hillslope growth patterns between perennials at Zap on one hand and 

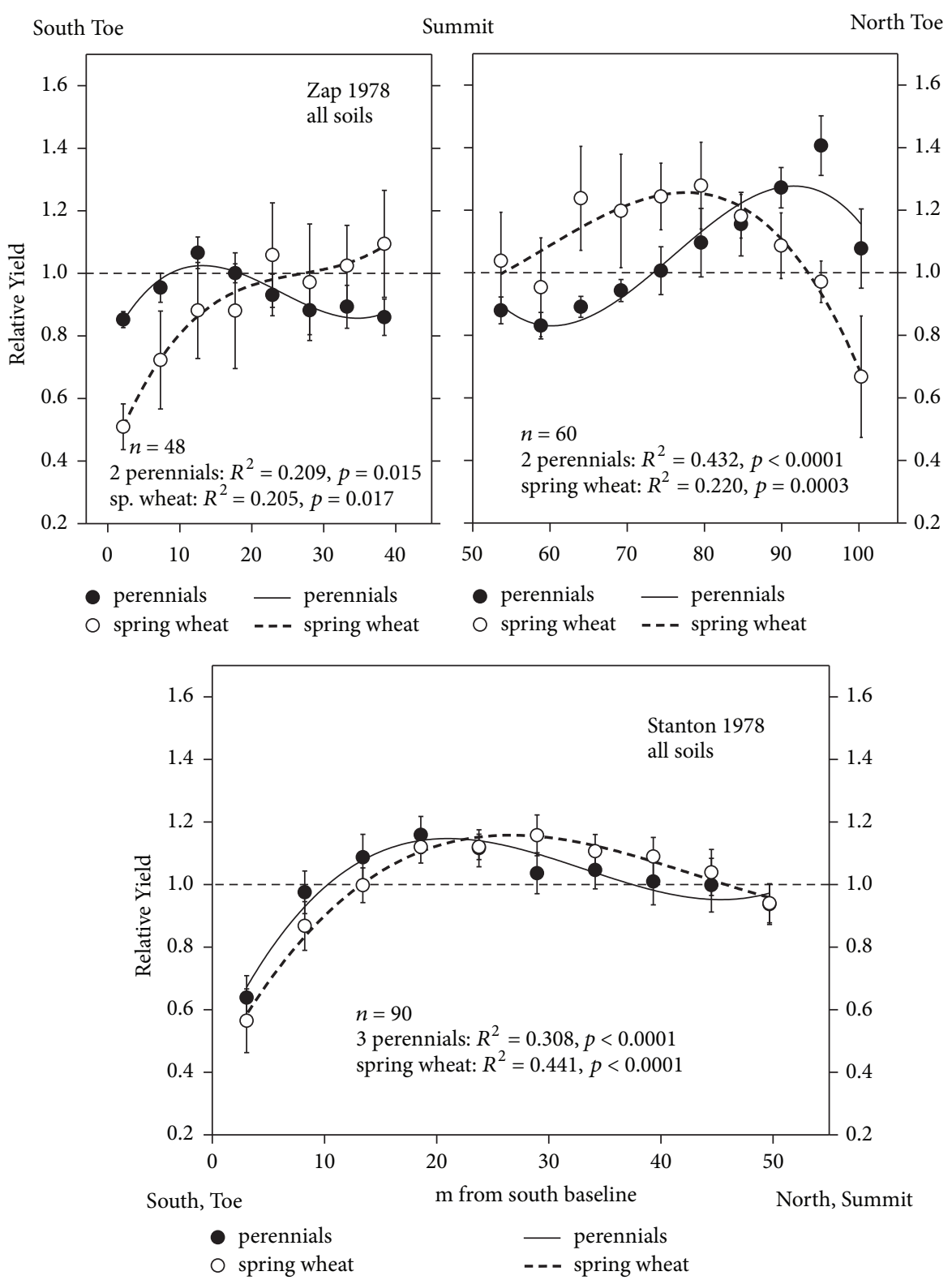

FIGURE 4: Relative yields versus hillslope positions comparing perennial forage crops' biomass and spring wheat seed for 1978 at Zap and Stanton sites showing means, standard errors, and cubic regressions. Soil treatments have been aggregated.

perennials at Stanton plus spring wheat at both sites appears to involve seasonality of growth and water use of the plant species at the sites.

Aspect is another factor that could have been involved in the differences in hillslope yield patterns between the sites. The Stanton site had a single $4 \%$ south-facing slope, making it less responsive to earlier-season water redistribution effects on plant growth than the 5\% north-facing slope at Zap. Examples exist in literature showing significantly greater soil water at north aspect positions compared to south aspect on Great Plains USA agricultural lands [25].

3.3. Application of Results. Current SQ assessment practice emphasizes management effects by examination of the most dynamic part of the profile near the soil surface, with emphasis placed on biological properties [26]. An earlier conception of SQ assessment included consideration of the entire rooting zone [27]. This study and its predecessors [2, 3] have shown growth responses to respread soil depths of $1 \mathrm{~m}$ or greater, indicating the value of a whole-rootzone approach to SQ assessment. A study of water use and movement at the Stanton site from 1978 to 1980 by Merrill et al. revealed that root growth occurred to at least a depth of $0.9 \mathrm{~m} \mathrm{[28].}$ Furthermore, this study showed that root growth and water use were occurring in mine spoil where soil depths were $0.9 \mathrm{~m}$ or less, an indication of macroporosity development in this material which initially has extremely low hydraulic conductivity. As noted above, we have used the $0-90 \mathrm{~cm}$ 
TABLE 4: (a) Correlations between distance from bottom (toe) of hillslopes and water redistribution index (WRI), respread soil depth (RSD), and soil quality index (SQI). (b) Correlation matrices for WRI, RSD, and SQI. (c) Correlations between SQI and soil properties. All $r$ values given have $p \leq 0.001$. AWC, available water content; EC, electrical conductivity; P, available phosphorus; SAR, sodium adsorption ratio; SOC, soil organic carbon.

(a)

\begin{tabular}{llrr}
\hline Site & WRI & RSD & SQI \\
\hline $\begin{array}{l}\text { Zap } \\
n=96\end{array}$ & Meters from south toe & -0.925 & 0.979 \\
$\begin{array}{l}\text { Zap } \\
n=120\end{array}$ & Meters from north toe & -0.978 & 0.946 \\
$\begin{array}{l}\text { Stanton } \\
n=180\end{array}$ & Meters from south toe & -0.981 & 0.934 \\
\hline
\end{tabular}

(b)

\begin{tabular}{lcccccc}
\hline $\begin{array}{l}\text { Zap, } \\
n=216\end{array}$ & WRI & RSD & SQI & $\begin{array}{c}\text { Stanton, } \\
n=180\end{array}$ & WRI & RSD \\
\hline WRI & 1 & -0.762 & -0.704 & WRI & 1 & -0.903 \\
RSD & -- & 1 & 0.890 & RSD & -- & 1 \\
SQI & -- & -- & 1 & SQI & -- & -- \\
\hline
\end{tabular}

(c)

\begin{tabular}{lccccrr}
\hline site & & SAR & EC & pH & AWC & SOC \\
\hline $\begin{array}{l}\text { Zap } \\
n=216\end{array}$ & SQI & -0.904 & -0.734 & -0.464 & ns & ns \\
$\begin{array}{l}\text { Stanton } \\
n=180\end{array}$ & SQI & -0.861 & -0.915 & -0.859 & 0.719 & 0.221 \\
\hline
\end{tabular}

TABLE 5: Linear and multilinear regressions of perennial forages' relative yields in 1978-79 versus water redistribution index (WRI), respread soil depth (RSD), and soil quality index (SQI) for soil treatments at Zap and Stanton sites. The third column in each group indicates the sign of regression coefficient(s). For entries with $p>0.10, R^{2}$ and other information are not given. At Zap and Stanton sites, $n=72$ and 60 , respectively. ns means multilinear regression coefficient has $p>0.10$.

\begin{tabular}{|c|c|c|c|c|c|c|c|c|c|}
\hline$X$-variable(s) & $R^{2}$ & $p$ & Coefficient sign & $R^{2}$ & $p$ & Coefficient sign & $R^{2}$ & $p$ & Coefficient sign \\
\hline & \multicolumn{3}{|c|}{ Zap 1978-79 } & \multicolumn{3}{|c|}{ Zap 1978-79 } & \multicolumn{3}{|c|}{ Zap 1978-79 } \\
\hline & \multicolumn{3}{|c|}{ Subsoil A } & \multicolumn{3}{|c|}{ Subsoil B } & \multicolumn{3}{|c|}{ Subsoil C } \\
\hline WRI & & 0.103 & & 0.123 & 0.003 & $\mathrm{P}^{\dagger}$ & 0.217 & $<0.001$ & $\mathrm{P}$ \\
\hline RSD & 0.074 & 0.021 & $\mathrm{~N}$ & 0.197 & $<0.001$ & $\mathrm{~N}$ & 0.188 & $<0.001$ & $\mathrm{~N}$ \\
\hline RSD + WRI & 0.074 & 0.069 & $\mathrm{~N} ; \mathrm{ns}$ & 0.197 & $<0.001$ & $\mathrm{~N} ; \mathrm{ns}$ & 0.225 & $<0.001$ & ns; P \\
\hline SQI & 0.075 & 0.020 & $\mathrm{~N}$ & 0.187 & $<0.001$ & $\mathrm{~N}$ & 0.221 & $<0.001$ & $\mathrm{~N}$ \\
\hline \multirow[t]{3}{*}{ SQI + WRI } & 0.076 & 0.066 & $\mathrm{~N}: \mathrm{ns}$ & 0.195 & $<0.001$ & $\mathrm{~N} ; \mathrm{ns}$ & 0.258 & $<0.001$ & $\mathrm{~N} ; \mathrm{P}$ \\
\hline & \multicolumn{3}{|c|}{ Stanton 1978-79 } & \multicolumn{3}{|c|}{ Stanton 1978-79 } & \multicolumn{3}{|c|}{ Stanton 1978-79 } \\
\hline & \multicolumn{3}{|c|}{$0 \mathrm{~cm}$ topsoil } & \multicolumn{3}{|c|}{$20 \mathrm{~cm}$ topsoil } & \multicolumn{3}{|c|}{$60 \mathrm{~cm}$ topsoil } \\
\hline WRI & \multicolumn{3}{|c|}{0.830} & \multicolumn{3}{|c|}{0.109} & \multicolumn{3}{|c|}{0.583} \\
\hline RSD & \multicolumn{3}{|c|}{0.418} & \multicolumn{3}{|c|}{0.479} & \multicolumn{3}{|c|}{0.639} \\
\hline RSD + WRI & \multicolumn{3}{|c|}{0.113} & 0.250 & $<0.001$ & $\mathrm{P} ; \mathrm{P}$ & 0.303 & $<0.001$ & $\mathrm{P} ; \mathrm{P}$ \\
\hline SQI & \multicolumn{3}{|c|}{0.386} & \multicolumn{3}{|c|}{0.243} & 0.284 & $<0.001$ & $\mathrm{P}$ \\
\hline SQI + WRI & \multicolumn{3}{|c|}{0.103} & 0.418 & $<0.001$ & $\mathrm{P} ; \mathrm{P}$ & 0.402 & $<0.001$ & $\mathrm{P} ; \mathrm{P}$ \\
\hline
\end{tabular}

${ }^{\dagger} \mathrm{P}=$ positive; $\mathrm{N}$ = negative.

depth for SQ indexing and analyses. What would appear to be most appropriate for disturbed lands reclamation practice is a synthesis of the near-surface and whole-rootzone approaches to SQ assessment.

Especially in subhumid or semiarid areas, use of soil water deeper in the rootzone can become important under limited precipitation. Evidence for the benefit of considering the whole profile in SQ assessment was given in Merrill et al. [29], where two taxonomically similar North Dakota USA Haplustoll soils with similar SQI values were compared. One had subsoil with higher hydraulic conductivity and good root penetrability and exhibited greater maize production under 


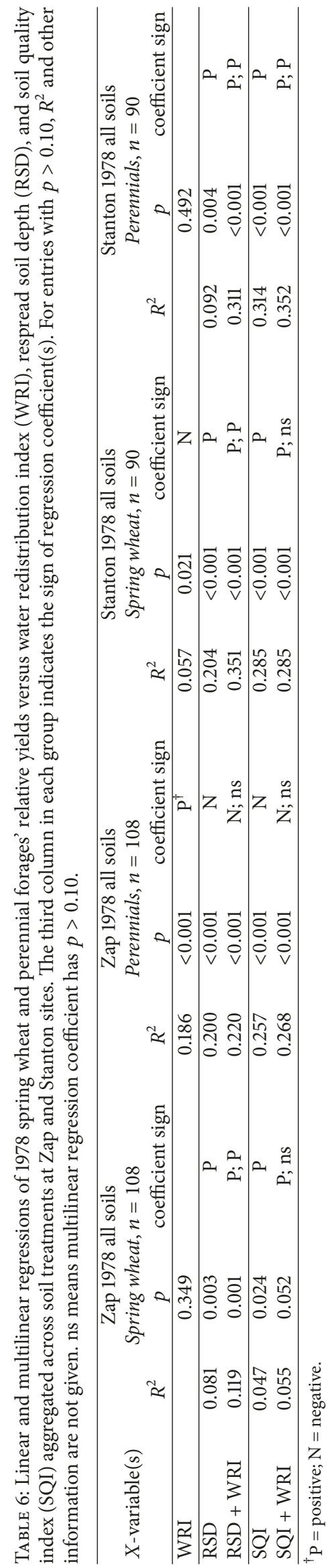


soil water limitation compared with the other soil, which had subsoil with higher clay content and apparently low hydraulic conductivity.

Much of the disturbed land in the northern Great Plains region, such as that used for research here, has been or will be reclaimed to rangeland/pastureland usage. According to Herrick et al. [30], SQ assessments of rangeland should include measures of plant community composition and structure along with soil properties to best gauge soil and land stability. They recommend aggregate stability of surface soil as a key indicator of resistance to erosion.

Our results have shown that interpretation of reclamation experiments by soil salvage and respreading requires consideration of both soil depth through SQ analysis and basic hillslope water redistribution process. Analysis of hillslope growth patterns and regression analyses have shown qualitative differences between the sites and among plant species types. These differences may be summarized: more dominance of apparent water redistribution effects for coolseason grasses at Zap site and dominance or more balanced influence of soil depth and associated SQ factors for spring wheat at both sites and forage species at Stanton.

To obtain more quantitative analyses of reclamation experiment results such as those studied here, we suggest an analysis model be implemented that combines hydrologic processes on the hillslope scale with plant growth responses to soil factors at the point scale. For example, hydrologists have described and implemented a distributed hydrological model [31] that divides the hillslope scale into space increments and uses mass balance to derive hydrologic components at each increment, such as runoff, infiltration, transpiration, and drainage to subsoil. Plant ecological and wateruse effects within the context of semiarid rangelands have been simulated with this model. The plant growth component of the Erosion Prediction Impact Calculator (EPIC) model [32] could be used for the growth response part of a hybrid hydrological-edaphic/ecological analysis model. The EPIC model accounts for plant water relations and root growth by soil depth increments. Our results have shown that plant species and associated phenology, such as seasonality of water use and growth, can affect hillslope growth pattern. McMaster et al. [33] have described a modern, standalone version of the plant growth portion of EPIC and discuss earlier versions used in other publically supported agroecosystem models in the USA.

\section{Conclusions}

We studied mined land reclamation experiments in the state of North Dakota, USA, in which salvaged topsoil and subsoil materials were respread on high-sodium mine spoils, forming low hillslopes. At the Zap site, hillslope yield patterns of coolseason forage grasses CWG and RWR were more dominated by apparent water redistribution effects (yield increasing downslope) than by growth responses to soil depth increasing upslope. Hillslope yield patterns of forage crops (ALF, CWG, and NAT mix) at Stanton site and of spring wheat at both sites were more dominated by response to increasing soil depths from toeslope to midslope areas, with lesser response to apparent water redistribution from midslope to shoulder slope areas.

A soil quality index (SQI) based on six soil indicator properties was highly correlated $(r>0.7)$ with respread soil depth. Regressions between forage species' yields and water redistribution index (WRI) were significant for two out of three soil treatments at Zap. Multilinear regressions of forage yield at Stanton with measures of SQ combined with WRI captured curvilinear hillslope yield patterns, and both linear and multilinear regressions of spring wheat yield with SQ measures were significant for the two sites.

The dominance of water redistribution effects on hillslope yield patterns at Zap, supported by regression analyses, appeared to be due to response of cool-season forage species to springtime runoff. Forages at Stanton and spring wheat at both sites are known to use soil water later in the season, and this was associated with hillslope yield patterns that were dominated by soil depth and SQ effects.

Our results show that assessment models for disturbed lands reclamation by soil respreading need to include information about plant community composition and phenology of growth and water use along with landform hydrology and SQ-soil structure information.

\section{Disclosure}

Inclusion of branded product information is for the benefit of the reader and does not imply preference nor endorsement by USDA-ARS.

\section{Conflicts of Interest}

The authors declare that there are no conflicts of interest regarding the publication of this paper.

\section{Acknowledgments}

The authors wish to acknowledge the leadership of the late Dr. J. F. Power in the mined land reclamation experiments upon which this paper is based.

\section{References}

[1] E. C. Doll, S. D. Merrill, and G. A. Halvorson, "Soil replacement for reclamation of strip mined lands in North Dakota," North Dakota Agricultural Experiment Station, Bulletin 514, Fargo, North Dakota, USA, 24 pp., 1984.

[2] J. F. Power, F. M. Sandoval, R. E. Ries, and S. D. Merrill, "Effects of Topsoil and Subsoil Thickness on Soil Water Content and Crop Production on a Disturbed Soill," Soil Science Society of America Journal, vol. 45, no. 1, p. 124, 1981.

[3] S. D. Merrill, R. E. Ries, and J. F. Power, "Subsoil characteristics and landscape position affect productivity of reconstructed mine soils," Soil Science Society of America Journal, vol. 62, no. 1, pp. 263-271, 1998.

[4] R. C. Barth and B. K. Martin, "Soil depth requirements for revegetation of surface-mined areas in Wyoming, Montana, and North Dekota," Journal of Environmental Quality, vol. 13, no. 3, pp. 399-404, 1984. 
[5] K. R. Harmoney, K. J. Moore, E. C. Brummer, C. Lee Burras, and J. R. George, "Spatial legume composition and diversity across seeded landscapes," Agronomy Journal, vol. 93, no. 5, pp. $992-$ 1000, 2001.

[6] T. E. Fiez, B. C. Miller, and W. L. Pan, "Winter wheat yield and grain protein across varied landscape positions," Agronomy Journal, vol. 86, no. 6, pp. 1026-1032, 1994.

[7] NDAC, "North Dakota Administrative Code, Title 69, Bismarck, North Dakota, USA, 2017," http://www.legis.nd.gov/ agency-rules/north-dakota-administrative-code.

[8] D. L. Karlen, M. J. Mausbach, J. W. Doran, R. G. Cline, R. F. Harris, and G. E. Schuman, "Soil quality: a concept, definition, and framework for evaluation," Soil Science Society of America Journal, vol. 61, no. 1, pp. 4-10, 1997.

[9] S. S. Andrews, D. L. Karlen, and J. P. Mitchel, "A comparison of soil quality indexing methods for vegetable production systems in northern California Agriculture," Ecosystems Environment, vol. 90, no. 1, pp. 25-45, 2002.

[10] S. S. Andrews, D. L. Karlen, and C. A. Cambardella, “The soil management assessment framework: a quantitative soil quality evaluation method," Soil Science Society of America Journal, vol. 68, no. 6, pp. 1945-1962, 2004.

[11] I. D. Moore, R. B. Grayson, and A. R. Ladson, "Digital terrain modelling: a review of hydrological, geomorphological, and biological applications," Hydrological Processes, vol. 5, no. 1, pp. 3-30, 1991.

[12] A. W. Western, R. B. Grayson, G. Blöschl, G. R. Willgoose, and T. A. McMahon, "Observed spatial organization of soil moisture and its relation to terrain indices," Water Resources Research, vol. 35, no. 3, pp. 797-810, 1999.

[13] C. A. Black, D. D. Evans, J. L. White, L. E. Ensminger, and F. E. Clark, Methods of Soil Analysis Part 2, Chemical and Microbiological Properties, Agronomy Monograph 9.2, C. A. Black, D. D. Evans, J. L. White, L. E. Ensminger, and F. E. Clark, Eds., American Society of Agronomy, Madison, Wisconsin, USA, 1965, 1550 pp. (approx.).

[14] F. M. Sandoval and J. F. Power, Laboratory methods recommended for chemical analysis of mined land spoils and overburden in western United States, USDA-ARS Handbook 525, U.S. Government Printing Office, Washington, District of Columbia, USA, 1978, pp. 31.

[15] C. A. Bower and L. V. Wilcox, C. A. Black, D. D. Evans, J. L. White, L. E. Ensminger, and F. E. Clark, Eds. American Society of Agronomy, Madison, Wisconsin, USA, 1965, pp. 933-951.

[16] M. Peech, Hydrogen-ion activity, in Methods of Soil Analysis Part 2, Chemical and Microbiological Properties, Agronomy Monograph 9.2, C. A. Black, D. D. Evans, J. L. White, L. E. Ensminger, and F. E. Clark, Eds., American Society of Agronomy, Madison, Wisconsin, USA, 1965, pp. 914-926.

[17] U.S. Salinity Laboratory, ExtractChem (software), U.S. Dept. Agriculture, Agricultural Research Service, Riverside, California, USA, 2017, https://www.ars.usda.gov/research/software/.

[18] L. E. Allison, Organic carbon, in Methods of Soil Analysis Part 2, Chemical and Microbiological Properties, Agronomy Monograph 9.2, C. A. Black, D. D. Evans, J. L. White, L. E. Ensminger, and F. E. Clark, Eds., American Society of Agronomy, Madison, Wisconsin, USA, 1965, pp. 1367-1378.

[19] S. R. Olsen and L. A. Dean, Phosphorus, in Methods of Soil Analysis Part 2, Chemical and Microbiological Properties, Agronomy Monograph 9.2, C. A. Black, D. D. Evans, J. L. White, and F. E. Clark, Eds., American Society of Agronomy, Madison, Wisconsin, USA, 1965, pp. 1035-1049.
[20] A. F. Wick, The effects of soil depth and soil characteristics on plant community development in North Dakota, University of Denver, Denver, Colorado, USA, 2004, pp., 204.

[21] G. W. Gee and J. W. Bauder, "Particle size analysis," in Methods of Soil Analysis Part 1, Physical and Mineralogical Methods, SSSA Book, A. Klute, Ed., 5, pp. 383-411, Soil Science Society of America and American Society of Agronomy, Madison, Wisconsin, USA, 2nd edition, 1986.

[22] S. C. Gupta and W. E. Larson, "Estimating soil water retention characteristics from particle size distribution, organic matter percent, and bulk density," Water Resources Research, vol. 15, no. 6, pp. 1633-1635, 1979.

[23] A. B. Frank and A. Bauer, "Rooting Activity and Water Use during Vegatative Development of Crested and Western Wheatgrass," Agronomy Journal, vol. 83, no. 5, p. 906, 1991.

[24] S. D. Merrill, A. L. Black, and A. Bauer, "Conservation tillage affects root growth of dryland spring wheat under drought," Soil Science Society of America Journal, vol. 60, no. 2, pp. 575-583, 1996.

[25] A. Y. Hanna, P. W. Harlan, and D. T. Lewis, "Soil Available Water as Influenced by Landscape Position and Aspectl," Agronomy Journal, vol. 74, no. 6, p. 999, 1982.

[26] D. E. Stott, D. L. Karlen, C. A. Cambardella, and R. Daren Harmel, "A soil quality and metabolic activity assessment after fifty-seven years of agricultural management," Soil Science Society of America Journal, vol. 77, no. 3, pp. 903-913, 2013.

[27] W. E. Larson and F. J. Pierce, "The dynamics of soil quality as a measure of sustainable management," in Defining Soil Quality for a Sustainable Environment, Chap. 3., SSSA Special Pub. No. 35, J. W. Doran, D. C. Coleman, D. F. Bezdicek, and B. A. Stewart, Eds., pp. 37-51, Soil Science Society of America and American Society of Agronomy, Madison, Wisconsin, USA, 1994.

[28] S. D. Merrill, S. J. Smith, and J. F. Power, "Effect of disturbed soil thickness on soil water use and movement under perennial grass.", Soil Science Society of America Journal, vol. 49, no. 1, pp. 196-202, 1985.

[29] S. D. Merrill, M. A. Liebig, D. L. Tanaka, J. M. Krupinsky, and J. D. Hanson, "Comparison of soil quality and productivity at two sites differing in profile structure and topsoil properties," Agriculture, Ecosystems \& Environment, vol. 179, pp. 53-61, 2013.

[30] J. E. Herrick, J. R. Brown, A. J. Tugel, P. L. Shaver, and K. M. Havstad, "Application of soil quality to monitoring and management: Paradigms from rangeland ecology," Agronomy Journal, vol. 94, no. 1, pp. 3-11, 2002.

[31] E. R. Vivoni, D. Entekhabi, R. L. Bras, and V. Y. Ivanov, "Controls on runoff generation and scale-dependence in a distributed hydrologic model," Hydrology and Earth System Sciences, vol. 11, no. 5, pp. 1683-1701, 2007.

[32] J. R. Williams, C. A. Jones, J. R. Kiniry, and D. A. Spanel, "EPIC crop growth model," Transactions of the ASAE, vol. 32, no. 2, pp. 497-511, 1989.

[33] G. S. McMaster, J. C. Ascough, D. A. Edmunds et al., "Simulating Unstressed Crop Development and Growth Using the Unified Plant Growth Model (UPGM)," Environmental Modeling \& Assessment, vol. 19, no. 5, pp. 407-424, 2014. 


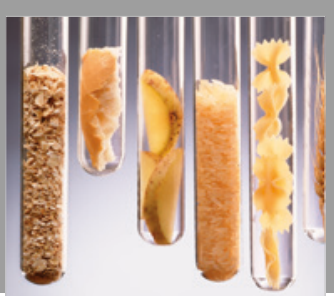

International Journal of Food Science

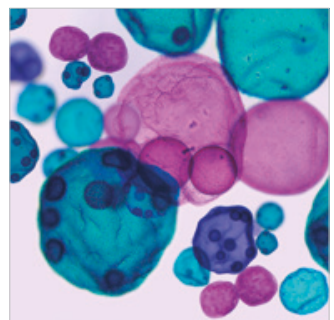

International Journal of Microbiology
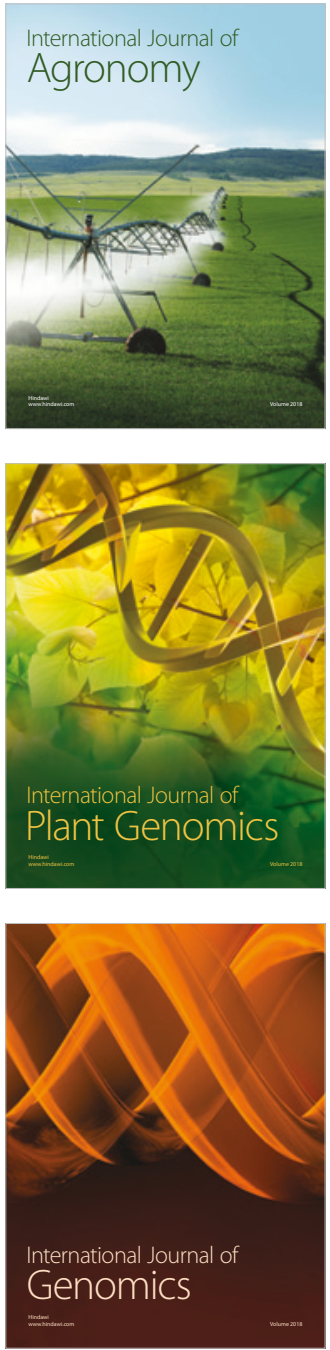

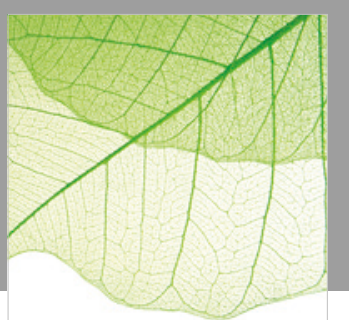

Journal of Botany
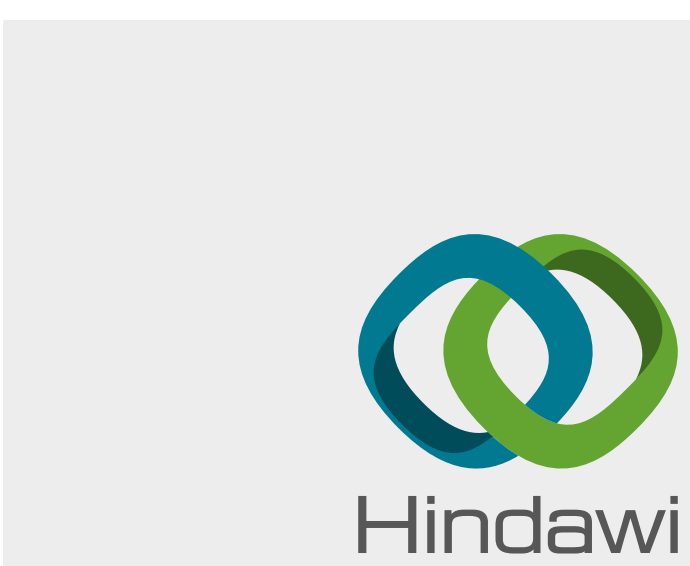

Submit your manuscripts at

www.hindawi.com
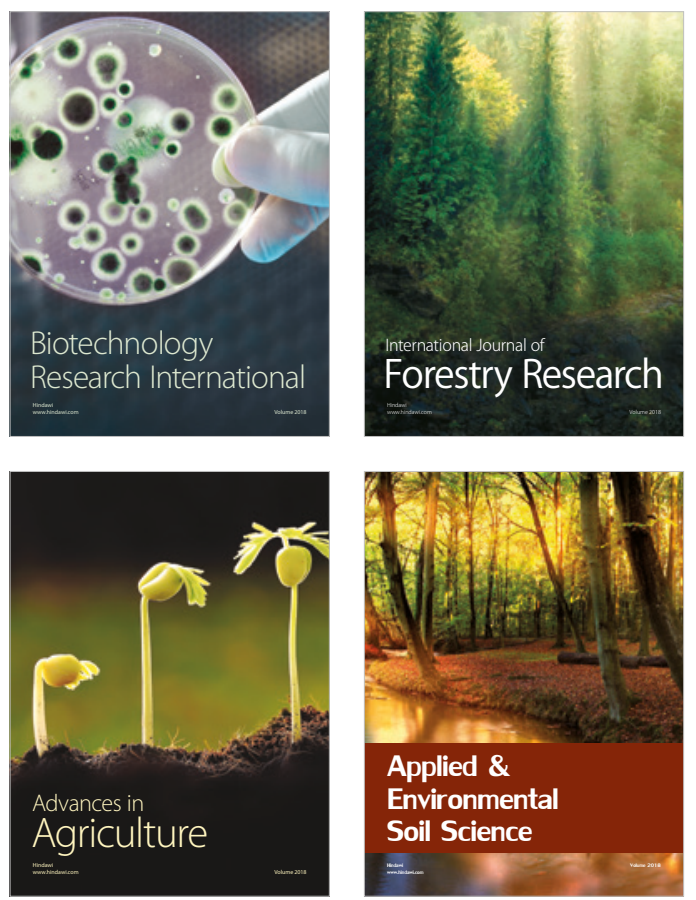

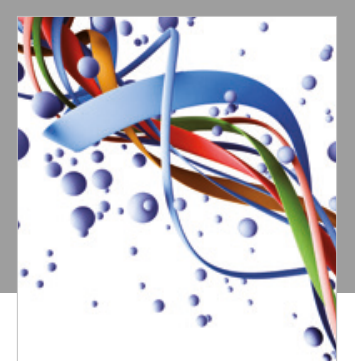

Scientifica

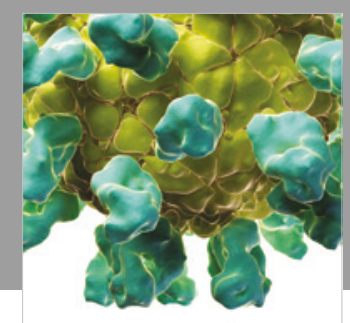

Veterinary Medicine International

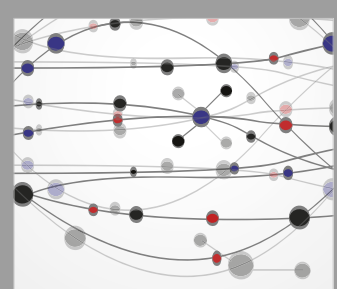

The Scientific World Journal
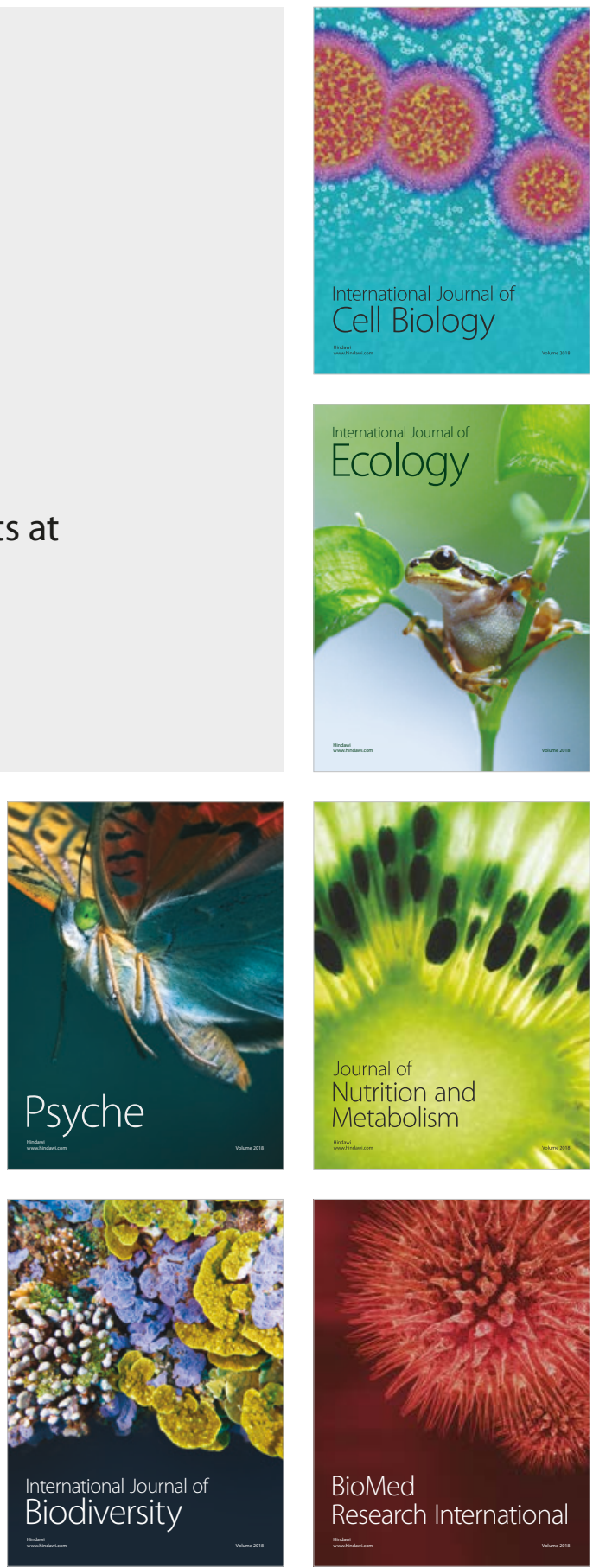